\title{
DE PARINTINS PARA TODO MUNDO VER: A FESTA DO BOI BUMBÁ DE PARINTINS SOB A PERSPECTIVA GLOBALITÁRIA'.
}

\author{
Diogo Labiak Neves ${ }^{2}$
}

Primeiramente cabe estabelecer uma diferenciação na concepção do objeto de estudo. Diferenciar a Festa do Boi Bumbá de Parintins ao Festival Folclórico de Parintins. Entendendo que o Festival Folclórico de Parintins ocorre todo ano nos fins do mês de junho. Dentro deste Festival, ocorrem as apresentações das duas agremiações. Diferenciar o Festival do conjunto de representações/manifestações que acontecem como preparatórias ao Festival Folclórico. Estas preparações acontecem sistematicamente durante a primeira metade do ano na cidade de Manaus, a estas representações preparatórias ao Festival associadas ao próprio Festival Folclórico de Parintins, chamo de Festa do Boi Bumbá de Parintins. Para a elaboração deste trabalho esta diferenciação se coloca de maneira vital. Outra diferenciação que se coloca pertinente é entre a representação social da manifestação cultural. Embora elas estejam entrelaçadas e indubitavelmente ligadas pretende-se estudar as relações sociais, embora não renegando o componente cultural que se faz presente e importante no social. As relações sociais que são fundamentadas na Festa do Boi Bumbá, bem como a Festa se coloca perante estas relações, apontam como pontos de principal interesse. Acredito que para estudar a questão cultural enquanto suas manifestações seria mais apropriado valer-se da diferenciação feita anteriormente entre Festa do Boi Bumbá e Festival Folclórico, adotando o segundo como principal meio de analise. Visto isto, para uma análise social e de suas representações me valho da Festa como "campo" ou "sujeito" de estudo.Agora, como estaria acontecendo esta transformação na festa? Estaria a Festa do Boi Bumbá de Parintins servindo de contraponto local à lógica que impera nestes últimos tempos? Ela pode ser encarada sob a ótica do processo contra-globalitário? Como se dá este processo contra-globalitário, se ele existe, e suas características?

PALAVRAS-CHAVE: festa do boi bumbá de Parintins; globalização; resistência contra-globalitária.

\footnotetext{
${ }^{1}$ Orientador: Prof. Dr. Luis Lopes Diniz Filho

${ }^{2}$ Mestrando em Geografia (UFPR) - e-mail: diogoufpr@yahoo.com.br
} 